\title{
Legen som skaffedyr
}

En lege kan hjelpe med så mangt - under forbudstiden med brennevin, i krigsårene med andre nødvendighetsvarer. I Tidsskriftet nr. 16/1940 kritiserte Hans Jacob Ustvedt i Om lægeattester for nødvendigheten av finsiktet hvetemel og hvetebrød sine yrkesbrødre for slepphendt utstedelse av attester. Responsen var stor - 19 innlegg kom på trykk før debatten ble avsluttet med en oppskrift på loff av sammalt mel i nr. 22. Her er et av bidragene (Tidsskr Nor Lægeforen 1940; 60: 749).

\section{Finsiktet hvetemel og større smørrasjoner.}

\section{Av H. F. Høst, Oslo}

H. J. Ustvedts artikkel om lægeattester for hvetemel i Tidsskriftets nr. 16 er et ord i rette tid. Det er forferdende å lese at det er utstedt mer enn 10000 slike attester bare i Oslo. Det er naturligvis lægenes «attestslapphet» gjennom mange år som har bragt publikum til å mene, at det er bare en formsak + et par kroner som skal til for å få attest, nær sagt for alt mulig. Et lite eksempel på hvad en kan oppleve er følgende brev jeg fikk for en tid siden:

«Herr overlæge - - -

Da mor har lyst å få hveteloff å spise vil jeg spørre Dem om hun kunde få lægeattest til hvetemel.»

I brevet, som var vanlig frankert, lå en «femmer». Det var sendt langveis fra og jeg erindret ikke pasienten; men kartoteket viste at det var en diabetespasient som jeg ikke hadde sett på år og som ikke hadde klaget over dyspepsi hos meg. - Så var det å skrive og forklare at dessverre var det ikke mulig å sende slik attest og dertil ha bryderi med å gå på postkontoret med pengebrev. Jeg har fătt flere slike henvendelser langveis fra, men heldigvis uten penger, et par ganger med returfrimerke. - Det ser ut til at det skal gå med hvetemelet som i sin tid med brennevinet.

Som hr. Ustvedt har også jeg funnet at den loff som lages av det vanlige sammalte mel er lett fordøyelig og tåles godt av praktisk talt alle fordøyelsespasienter, bortsett fra pasienter med utpreget intestinal gjæringsdyspepsi, forbundet med sterk gasdannelse og løse avføringer.

Et annet spørsmål er økede smørrasjoner hos diabetikere. Flere diabetikere er angivelig sendt fra rasjoneringskontorene med beskjed om «bare å få lægeattest» så vil større smørrasjoner kunne opnåes. Lette tilfelle av diabetes som klarer seg uten insulin, men som må leve på innskrenket kullhydrattilførsel, kan utvilsomt ha behov for mer smør, særlig hvis det er vanskelig å skaffe andre fettholdige næringsmidler som for eks. flesk. Men diabetikere som bruker insulin og som derved er i stand til å spise tilnærmelsesvis alminnelig kost, trenger etter min mening ikke mer smør enn sunne mennesker. 